\title{
Eemian tropical and subtropical African moisture transport: an isotope modelling study
}

\author{
Marcus Herold · Gerrit Lohmann
}

Received: 20 June 2008/ Accepted: 16 December 2008

(C) Springer-Verlag 2009

\begin{abstract}
During the last interglacial insolation maximum (Eemian, MIS 5e) the tropical and subtropical African hydrological cycle was enhanced during boreal summer months. The climate anomalies are examined with a General Circulation Model (ECHAM4) that is equipped with a module for the direct simulation of ${ }^{18} \mathrm{O}$ and deuterium $\left(\mathrm{H}_{2}^{18} \mathrm{O}\right.$ and $\mathrm{HDO}$, respectively) in all components of the hydrological cycle. A mechanism is proposed to explain the physical processes that lead to the modelled anomalies. Differential surface heating due to anomalies in orbital insolation forcing induce a zonal flow which results in enhanced moisture advection and precipitation. Increased cloud cover reduces incoming short wave radiation and induces a cooling between $10^{\circ} \mathrm{N}$ and $20^{\circ} \mathrm{N}$. The isotopic composition of rainfall at these latitudes is therefore significantly altered. Increased amount of precipitation and stronger advection of moisture from the Atlantic result in isotopically more depleted rainfall in the Eemian East African subtropics compared to pre-industrial climate. The East-West gradient of the isotopic rainfall composition reverses in the Eemian simulation towards depleted values in the east, compared to more depleted western African rainfall in the pre-industrial simulation. The modelled re-distribution of $\delta^{18} \mathrm{O}$ and $\delta \mathrm{D}$ is the result of a change in the forcing of the zonal flow anomaly. We conclude that the orbitally induced forcing for African monsoon maxima
\end{abstract}

\footnotetext{
M. Herold $(\bowtie) \cdot$ G. Lohmann

Alfred Wegener Institute for Polar and Marine Research, Bremerhaven, Germany

e-mail: marcus.herold@awi.de

M. Herold · G. Lohmann

MARUM, Center for Marine Environmental Sciences, Bremen, Germany

e-mail: gerrit.lohmann@awi.de
}

extends further eastward over the continent and leaves a distinct isotopic signal that can be tested against proxy archives, such as lake sediment cores from the Ethiopian region.

\section{Introduction}

Changes in the African hydrological cycle, in particular the rain belt position and intensity, are crucial for the local population, since the northern boundary of the rain belt position determines the northernmost edge of the inhabitable area. Studying the evolution of the rain belt and the associated physical processes in the past may allow us to better understand climate projections for this region. The previous interglacial maximum (Eemian, MIS 5e) is in this respect a valuable period, since climatic conditions were similar to the present day. The number of terrestrial proxy archives of Eemian climate is small compared to the amount of data available from the Holocene. However, climate archives point at the following: During the Eemian, the annual mean global temperatures were not significantly higher than today (Jansen et al. 2007). However, there were large regional as well as seasonal anomalies (e.g. Jouzel et al. 1987; Lohmann and Lorenz 2007). During Northern Hemisphere $(\mathrm{NH})$ summers the rain belt advanced northwards, increasing the area on the African continent that was influenced by the summer monsoon.

Previous studies examine the effects of these meridional shifts of the Intertropical Convergence Zone (ITCZ) and associated seasonal rainfall variations. It is generally accepted that the rain belt itself has never reached North Africa (Tzedakis 2007). The influence only reached the Mediterranean via river discharge from the Nile. East 
Mediterranean sapropels are used as recorder of terrestrial African climate archives (Rossignol-Strick 1983; Rohling et al. 2002). These layers of anoxic organic-rich material in sediments are the result of heavy discharge of the Nile river during times of maximum summer monsoon index (Rossignol-Strick 1983; van der Meer et al. 2007). The impact of the rain belt (or ITCZ) on sapropel formation during the summer months depends on how far the precipitation area advanced northward. This has been analysed by comparing differences between East Mediterranean sediment cores that were influenced by the vast Nile river catchment area and those only recording information from the region directly adjacent to the Mediterranean (Rohling et al. 2002). Similar effects are observed for the Indian monsoon in the Eemian (Fleitmann et al. 2003) and in the mid-Holocene period (Fleitmann et al. 2007). In these studies, speleothems from the sensitive region of southern Oman recorded meridional shifts of the convergence zone and associated changes in precipitation source and amount.

The purpose of this study is to explain the substantial changes in the African tropical and subtropical hydrological cycle, which are evident from observed Mediterranean sediments and speleothems from regions that are sensitive to changes in the tropical rain belt. We examine an orbitally forced climatic anomaly that may have similar effects as observed in the sapropel sections of Eemian Mediterranean sediments. This poses the question whether there exists a mechanism that explains the direct and indirect effects of the orbital insolation forcing. Most importantly, we will show that the modelled isotopic composition of rainfall is in accordance with observed evidence from Mediterranean sediments and stalagmites from Southern Oman.

Modelling of interglacial climates became more realistic with the use of coupled ocean atmosphere general circulation models (OAGCMs). These studies indicate increased amounts of boreal summer precipitation in northern subtropical Africa in climatic conditions with increased $\mathrm{NH}$ insolation and increased insolation seasonality (Montoya et al. 2000; Felis et al. 2004; Schurgers et al. 2007). Under these orbital forcing anomalies, the temperature difference between the North Atlantic and the African continent increases, moisture transport and precipitation towards subtropical North Africa is enhanced (e.g., Kutzbach and Liu 1997). Therefore, North African vegetation differed from the present-day distribution. The Eemian and midHolocene climates allowed plant growth in areas which today are part of the Sahara desert. The influence of a different interglacial vegetation on the large-scale circulation has been widely discussed (e.g., Kutzbach and Liu 1997; Doherty et al. 2000; Braconnot et al. 2007). The Eemian is also characterised by a reduction of the Greenland Ice Sheet (GIS). During the Eemian, a reduction of the GIS may have contributed to sea-level rise of up to 3 meters (Otto-Bliesner et al. 2006), which is $50 \%$ of the sea-level rise after total melting of the ice sheet. Lhomme et al. (2005) estimate the Greenland contribution to sea-level rise to be 3.5-4 m.

We use the results of a coupled ocean-atmosphere-seaice general circulation model, plus a module for the direct simulation of heavy isotopic water in the hydrological cycle to examine the effect of Eemian orbital forcing on the isotopic rainfall composition on the African continent. The stable isotopes ${ }^{18} \mathrm{O}$ and deuterium (D) record changes in the hydrological cycle. At higher latitudes, anomalies in the isotopic composition of precipitation mainly reflect changes in the surface temperature at the precipitation site. In the tropics, changes in the amount of precipitation are responsible for its isotopic composition (e.g. Jouzel et al. 2000). Additionally, nonlocal effects, such as global ice volume or temperature at the moisture source have an impact on isotopic records of any given site. The relationships between $\delta^{18} \mathrm{O}$ and temperature or precipitation amount vary with forcing as a consequence of changes in seasonality and transport pathways (Schmidt et al. 2007). Felis et al. (2004) already examined that temperatures are not only directly linked to changes in external forcing, but also to the changes in the large-scale atmospheric circulation, which responds to change in forcing. The coral data in Felis et al. (2004) indicate an enhanced seasonality in the middle East and a tendency towards positive North Atlantic Oscillation during the Eemian.

Indirect evidence for changes in the hydrological cycle can be found in the isotopic composition of Eastern Mediterranean sediments from sapropel S5 (Rohling et al. 2004). Depleted $\delta^{18} \mathrm{O}$ values from this period indicate an increased African monsoon activity, recorded via Nile river discharge into the Mediterranean. The spatial distribution of $\delta^{18} \mathrm{O}$ and $\delta \mathrm{D}$ in our simulations indicates that changes in zonal moisture transport rather than a meridional shift in the ITCZ alter the hydrological cycle and trigger the observed northward extension of the rainfall area.

In Sect. 2 we introduce the setup of boundary conditions and the modelling technique. In Sect. 3 we present the relevant results concerning the thermodynamical anomalies in the hydrological and the isotopic response of meteoric water. In Sect. 4 we discuss our findings and present a mechanism to explain the modelled anomalies. Conclusions and a brief overview over the limitations of our study and possible future work are given in Sect. 5.

\section{Methods}

The atmospheric general circulation model (AGCM) ECHAM was adapted for climate research by the Max Planck Institute for Meteorology in Hamburg from the weather forecasting model of the European Centre for 
Medium-Range Weather Forecasts (ECMWF). The fourthgeneration member of the ECHAM family, ECHAM4, is equipped with a module for the direct simulation of the stable isotopes ${ }^{18} \mathrm{O}$ and deuterium in all components of the atmospheric water cycle (Werner et al. 2001). For each phase of the normal water $\left(\mathrm{H}_{2}^{16} \mathrm{O}\right)$ an isotopic counterpart $\left(\mathrm{H}_{2}^{18} \mathrm{O}, \mathrm{HD}^{16} \mathrm{O}\right)$ is transported independently (Hoffmann et al. 1998). The heavier isotopic water molecules $\mathrm{H}_{2}^{18} \mathrm{O}$ and ${ }^{2} \mathrm{H}^{1} \mathrm{H}^{16} \mathrm{O}$ (HDO) are stable and have no sources or sinks on time scales that are considered in this study. Therefore, they can be used as tracers in the hydrological cycle. $\mathrm{H}_{2}^{18} \mathrm{O}$ and $\mathrm{HDO}$ are affected by fractionation processes due to their molecular weight and (in the case of HDO) asymmetry. Isotopic composition is calculated in permil with respect to VSMOW (Vienna Standard Mean Ocean Water) as shown by Craig (1961). Both equilibrium fractionation and kinetic fractionation effects are taken into account.

The water isotopes are transported in parallel to atmospheric water. The advection and diffusion routines therefore ensure constant ratios of $\mathrm{H}_{2}^{18} \mathrm{O} / \mathrm{H}_{2}^{16} \mathrm{O}$ and $\mathrm{HDO} /$ $\mathrm{H}_{2}^{16} \mathrm{O}$, respectively. The isotopic composition is then expressed in terms of VSMOW, the Vienna standard mean ocean water. For ${ }^{18} \mathrm{O}$ we use the formula

$\delta^{18} \mathrm{O}=\left[\left({ }^{18} \mathrm{O} /{ }^{16} \mathrm{O}\right)_{\text {sample }} /\left({ }^{18} \mathrm{O} /{ }^{16} \mathrm{O}\right)_{\text {VSMOW }}-1\right]$.

$\delta \mathrm{D}$ is calculated correspondingly for $\mathrm{HD}^{16} \mathrm{O}$. The first fractionation process occurs during evaporation at the ocean surface. The evaporative flux of isotopes is calculated using

$E_{x}=\rho C_{v}\left|\mathbf{v}_{h}\right|(1-k)\left(x_{\mathrm{vap}}-x_{\mathrm{sat}}\right)$

where $\rho$ is the density of air, $C_{v}$ the drag coefficient depending on the stability of the atmospheric boundary layer, $\left|\mathbf{v}_{h}\right|$ the horizontal wind speed, $x_{\text {vap }}$ the water isotope mixing ratio in the first model layer, and $x_{\text {sat }}=\alpha\left(T_{\text {surf }}\right)^{-1} \beta$ $R_{\text {oc }} q_{\text {sat }}$, with $\alpha$ the temperature-dependent equilibrium fractionation factor, $\beta$ an enrichment factor for the oceanic surface due to evaporation, $R_{\mathrm{oc}}$ the oceanic mass relation corresponding to $R_{\mathrm{SMOW}}$, and $q_{\mathrm{sat}}$ is the saturation mixing ratio. Non-equilibrium effects (kinetic diffusion from the thin sub-layer above the ocean surface to the atmosphere) are taken into account with the factor $1-k$ (see Merlivat and Jouzel 1979). Dividing $E_{x}$ by the evaporative flux of $\mathrm{H}_{2}^{16} \mathrm{O} E=\rho C_{v}\left|\mathbf{v}_{h}\right|\left(q_{\text {vap }}-q_{\text {sat }}\right)$ results in the isotopic composition of the evaporative flux

$$
\begin{aligned}
& \delta E_{x}+1=(1-k) /(1-h)\left[\alpha\left(T_{\text {surf }}\right)^{-1}\left(\delta x_{\mathrm{oc}}+1\right)\right. \\
& \left.-\left(\delta x_{\text {vap }}+1\right) h\right]
\end{aligned}
$$

with $\delta x_{\mathrm{oc}}=\beta\left(R_{\mathrm{oc}} / R_{\mathrm{SMOW}}\right)-1$, the relative humidity $h$, and the atmospheric delta-value $\delta x_{\text {vap }}$.
Condensation to liquid or ice phase is treated as an equilibrium process $\left(R_{l, i}=\alpha R_{\mathrm{vap}}\right)$.

A kinetic process becomes important at low temperatures, namely the diffusion of isotopes through the oversaturated zone around forming ice crystals. This is considered in the model with an effective fractionation coefficient

$\alpha_{\text {eff }}=\alpha_{\text {eq }} \alpha_{\text {kin }}$

with $\alpha_{\text {kin }}=S /\left(\alpha_{\mathrm{eq}} R_{D}(S-1)+1\right) . R_{D}$ is the ratio of the diffusivities of $\mathrm{H}_{2}^{16} \mathrm{O}$ and the isotopic water, and $S=1+0.003 T\left(T\right.$ in $\left.{ }^{\circ} \mathrm{C}\right)$ the oversaturation function (see Hoffmann et al. 1998).

Re-evaporation of raindrops in the undersaturated air below cloud base occurs in an equilibrium and non-equilibrium process: the kinetic fractionation is formulated similar to Eq. 2, using undersaturation described by $h_{\text {eff }}$, the mean relative humidity of the air below cloud base in the grid box. The fraction of droplets that reach isotopic equilibrium depends on the droplet size. Since there is no droplet size spectrum in ECHAM, we assume that $45 \%$ of convective precipitation and $95 \%$ of large-scale precipitation equilibrate.

The spatial resolution of the simulations in the present study is T42 $\left(2.8^{\circ}\right.$ horizontal spacing $)$ with 19 vertical levels and the highest pressure level at $10 \mathrm{hPa}$. Two simulations representing the periods of pre-industrial climate and Eemian climate (124 ka BP), respectively, have been carried out. In the following, experiment names represent the respective period $(\mathrm{PI}=$ pre-industrial, $\mathrm{EEM}=124 \mathrm{ka}$ $\mathrm{BP})$. The integration time is 70 model years, with the first 10 years neglected and 60 years used for averaging the results. This is found to be sufficient to ensure statistical significance of the modelled anomalies.

Boundary and initial conditions are used as follows: Insolation is calculated with orbital parameters according to Berger (1978). Boreal summer tropical and northern subtropical insolation is increased, while tropical winter solar radiation is weaker in the Eemian compared to preindustrial time. The insolation anomalies led to increased NH seasonality, while the Southern Hemisphere seasonality decreased in the Eemian (Felis et al. 2004; Lohmann and Lorenz 2007). Climatologies of monthly sea surface temperatures as bottom-boundary conditions have been taken from previous simulations with the coupled oceanatmosphere model setup ECHO-G (Lorenz and Lohmann 2004; Lohmann and Lorenz 2007), the atmospheric part of which is ECHAM4, and the ocean is modelled with the ocean GCM HOPE (Legutke and Voss 1999). The isotope initial data have been set up in an ECHAM4 initial run, in which the atmosphere is started with a $\delta^{18} \mathrm{O}$ value of $-80 \%$ and reaches an equilibrium state, which is used for the following case studies. 
Greenhouse gases and vegetation are kept at pre-industrial levels. To take into account the Eemian climatic anomalies, we performed two sensitivity studies to test the robustness of the phenomena we found in the EEM simulation. One simulation includes extended vegetated Sahara areas. The surface vegetation parameters on the African continent are increased by a factor of $\mathrm{X}_{\text {mean }} / \mathrm{X}$ at the grid points between $10^{\circ} \mathrm{N}$ and $25^{\circ} \mathrm{N}$, where $X_{\text {mean }}$ is the mean parameter of the grid points between $10^{\circ} \mathrm{W}$ and $40^{\circ} \mathrm{E}$ at the latitude $10^{\circ} \mathrm{N}$. In the second sensitivity simulation, the height of the GIS is reduced by a factor of 0.5 . In the following, these two sensitivity studies are named EEM $_{\mathrm{VEG}}$ and $\mathrm{EEM}_{\mathrm{GIS}}$, respectively.

\section{Results}

\subsection{Climate variables}

Figure 1a, b show the differences of air temperature and horizontal wind vectors between EEM and PI. In the following we will use the term anomaly as deviation of the EEM simulation results from the PI simulation. The $850 \mathrm{hPa}$ level (Fig. 1a) lies in the lower troposphere and is partly influenced by surface features. Below $850 \mathrm{hPa}$, the flow and its anomalies are influenced by the topography, such as the Ethiopian Highlands south of the Red Sea. A belt of lower air temperature stretches from the African continent between $10^{\circ} \mathrm{N}$ and $20^{\circ} \mathrm{N}$ over the southern Red Sea and the Arabian Sea towards northern India. The air temperature is reduced by $3 \mathrm{~K}$ in the Eemian relative to pre-industrial climate. North of this belt, there is widespread warming over northern Africa, Europe, Arabia and Central Asia with the highest anomalies at $4 \mathrm{~K}$. The air temperature directly south of the belt is almost unchanged. As we will see later, this cooling is related to enhanced cloud cover and increased evaporative cooling.

In the upper troposphere (Fig. 1b), the warming extends southward over the entire African continent. The cool belt is therefore limited to the lower and middle troposphere. The tropopause and stratosphere were colder in EEM as compared to PI (not shown), due to tropospheric warming in the last interglacial.

The difference between EEM and PI is characterised by a pressure anomaly, with a lower-tropospheric low pressure anomaly in areas where the warming affects the whole troposphere. Figure $2 \mathrm{a}$ shows the anomaly of the geopotential height. A pronounced feature is the meridional gradient in the pressure anomaly at the location of the low temperature belt (see Fig. 1a). The larger pressure gradient causes a stronger eastward zonal flow according to geostrophy dynamics. In contrast to the mid-latitudinal thermal wind relation, we observe in the latitudinal band between $10^{\circ} \mathrm{N}$ and $20^{\circ} \mathrm{N}$ that the largest wind anomalies do not occur at the largest temperature gradients. Instead, the pressure distribution rather suggests that the belt of cool air is a consequence of the larger difference in surface temperature between Sahara/Sahel and tropical Africa.

In the upper troposphere (Fig. 2b) the pressure anomaly is reversed, since the large-scale warming in EEM extends throughout the troposphere with higher geopotential height of the corresponding pressure levels (i.e., higher pressure at a given height). Consequently, the wind anomaly is also reversed, and the westward zonal flow is stronger in the

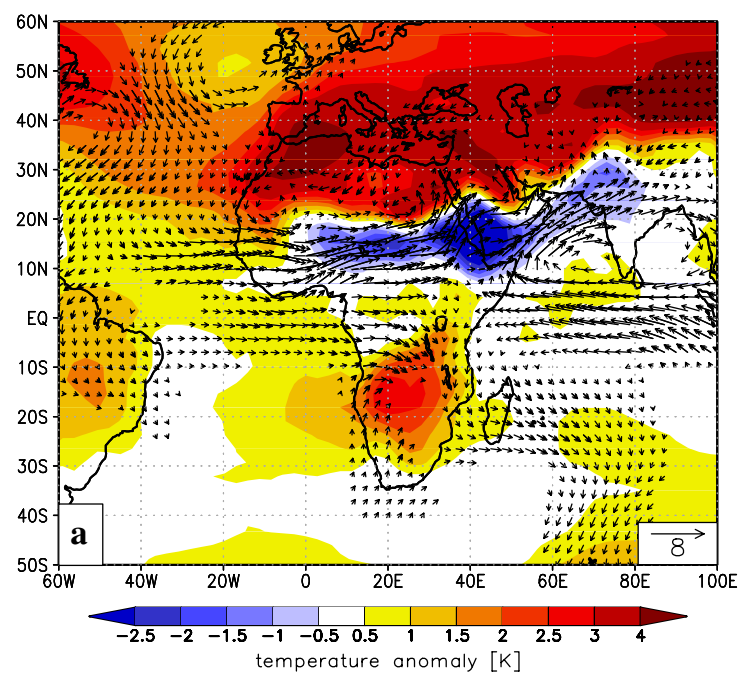

Fig. 1 Anomalies (EEM minus PI) of modelled air temperature in $\mathrm{K}$ (colours) and horizontal wind in $\mathrm{m} / \mathrm{s}$ (arrows), of a $850 \mathrm{hPa}$, and $\mathbf{b}$ $300 \mathrm{hPa}$ level. Reference arrows in m/s are shown in the lower right

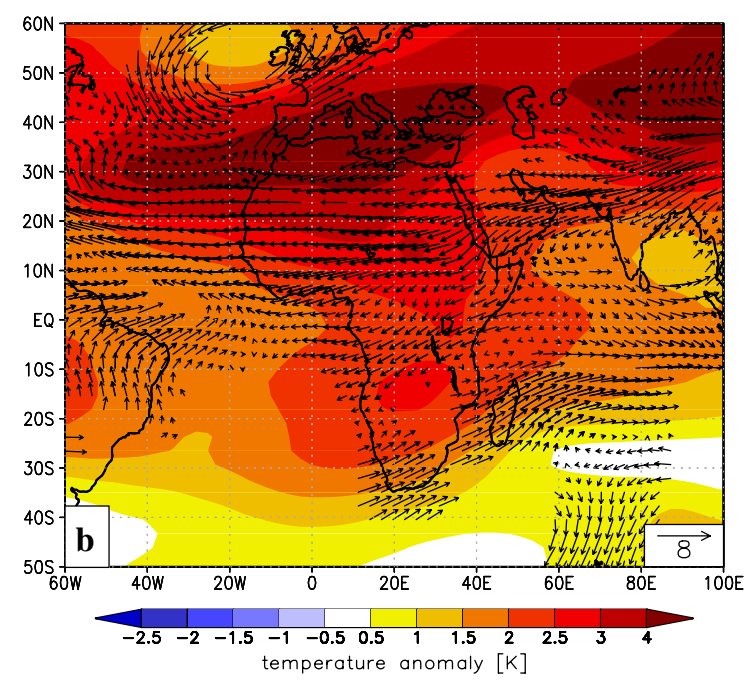

corner of the panels. Only wind arrows with anomalies in at least one component above $90 \%$ significance level are shown 

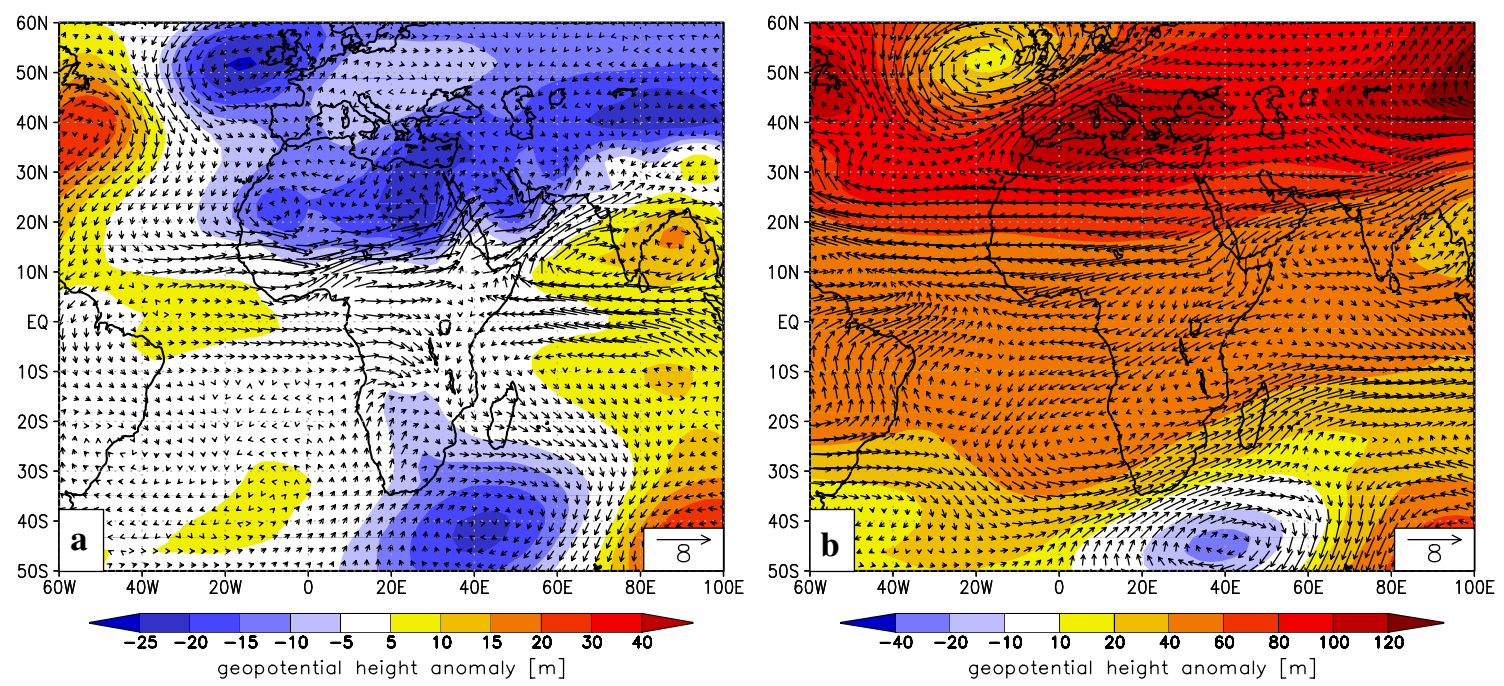

Fig. 2 Anomalies (EEM minus PI) of modelled horizontal wind in $\mathrm{m} / \mathrm{s}$ (arrows), and geopotential height in $\mathrm{m}$ (colours) of a $850 \mathrm{hPa}$, and $\mathbf{b} 300 \mathrm{hPa}$ level. Reference arrows in $\mathrm{m} / \mathrm{s}$ are shown in the lower right corner of the panels


Fig. 3 Boreal summer (JJA) anomalies (EEM minus PI) of a precipitation (in mm/month) and b specific humidity (in $\mathrm{g} / \mathrm{kg}$ at $850 \mathrm{hPa}$ level). Dashed areas indicate significant anomalies at $90 \%$ level

Eemian than in the pre-industrial simulation. At this height, the pressure anomaly resembles the temperature anomaly (Fig. 1b).

The EEM simulation shows increased precipitation amounts on the African continent between $10^{\circ} \mathrm{N}$ and $20^{\circ} \mathrm{N}$, in the whole Red Sea region, northern Arabian Sea, and northern India (Fig. 3a, b). Absolute values of the flow pattern (not shown) reveal that not only the strength of the zonal flow changed between EEM and PI, but also the direction. In PI, the flow reveals hardly any zonal component, whereas in the Eemian the zonal wind component is present throughout the continent between $10^{\circ} \mathrm{N}$ and $20^{\circ} \mathrm{N}$.

There is also a difference in meridional extent of the main low-level convergence zone of only $2^{\circ}$ in Central Africa. Figure 4 shows the seasonally averaged vertical velocity over Africa. The mid-tropospheric convection zone (500 hPa, Fig. 4a) is displaced northward in EEM compared to PI. The maximum updraft area is narrower, and the maximum value of the mean vertical velocity is about $10 \%$ larger, reflecting a more intense convective activity due to the converging zonal flow in the EEM simulation. The anomalies in convection intensity extend throughout the troposphere. At $300 \mathrm{hPa}$ (Fig. 4b) the relative anomaly even increases while absolute differences between EEM and PI are declining at this height.

Figure 5a shows the decrease of surface solar radiation along with an increase of total cloud cover in the region. There is no uniform response of evaporation rates during the Eemian (Fig. 5b). Two regimes of evaporation anomalies can be identified. The northern part of the rain belt shows increased evaporation rates of up to $50 \mathrm{~mm} / \mathrm{month}$ 



Fig. 4 EEM (colours) and PI (contours) boreal summer (JJA) mean vertical velocity component at a $500 \mathrm{hPa}$ and b $300 \mathrm{hPa}$ level, respectively. Units are $\mathrm{Pa} / \mathrm{s}$. Negative values indicate mean updraft areas

over the Red Sea region, whereas the southern part of the rain belt shows negative evaporation anomalies.

Figure $6 \mathrm{a}, \mathrm{b}$ show a north-south cross-section of tropospheric anomalies at $10^{\circ} \mathrm{E}$ up to a pressure level of $300 \mathrm{hPa}$. The main zonal transport of moisture (Fig. 6a) is located between $10^{\circ} \mathrm{N}$ and $20^{\circ} \mathrm{N}$, and below the $500 \mathrm{hPa}$ level, indicated by positive anomalies in zonal wind and specific humidity. South of about $5^{\circ} \mathrm{N}$, there is even a negative moisture anomaly, which corresponds to red shades (less rain and less specific water content) in Fig. 3b. Figure $6 b$ shows the corresponding temperature anomalies and the anomalies of the geopotential height of the pressure levels. North of about $20^{\circ} \mathrm{N}$ the vertical gradient of the pressure anomaly leads to the modelled wind anomalies (see Figs. 1, 2 , respectively). The cool belt between $10^{\circ} \mathrm{N}$ and $20^{\circ} \mathrm{N}$ is limited to the lower troposphere below $800 \mathrm{hPa}$.

\subsection{Isotopes}

The differences between EEM and PI in the wind and precipitation patterns are also reflected in the isotopic composition of modelled atmospheric water. Figure 7 shows anomalies in the isotopic signature of the total precipitation. The magnitude of the deuterium signal is larger than the ${ }^{18} \mathrm{O}$-signal. However, the panels of both simulated isotopes correspond qualitatively very well, as the same physical processes lead to the modelled isotopic composition. The differences between Eemian and presentday simulations are large in boreal summer and are not pronounced during the winter months and are therefore not shown. For the boreal summer, both deuterium and ${ }^{18} \mathrm{O}$ show an increase on the West African continent, and a decrease in the East African subtropics and the Red Sea region in the Eemian climate. This corresponds to a reversal of the gradients of the absolute isotopic values (Fig. 8). In the PI simulation (Fig. 8a), western African precipitation is isotopically lighter than eastern African precipitation. This corresponds to the measured presentday isotope distribution as recorded in the GNIP climatology (Rozanski et al. 1993). In EEM (Fig. 8b), there is a much stronger gradient from slightly negative values in the west towards strongly depleted rainfall in the east.

Figure 9 shows that the pronounced summer anomalies leave an imprint in the annually averaged signal. Here, we 

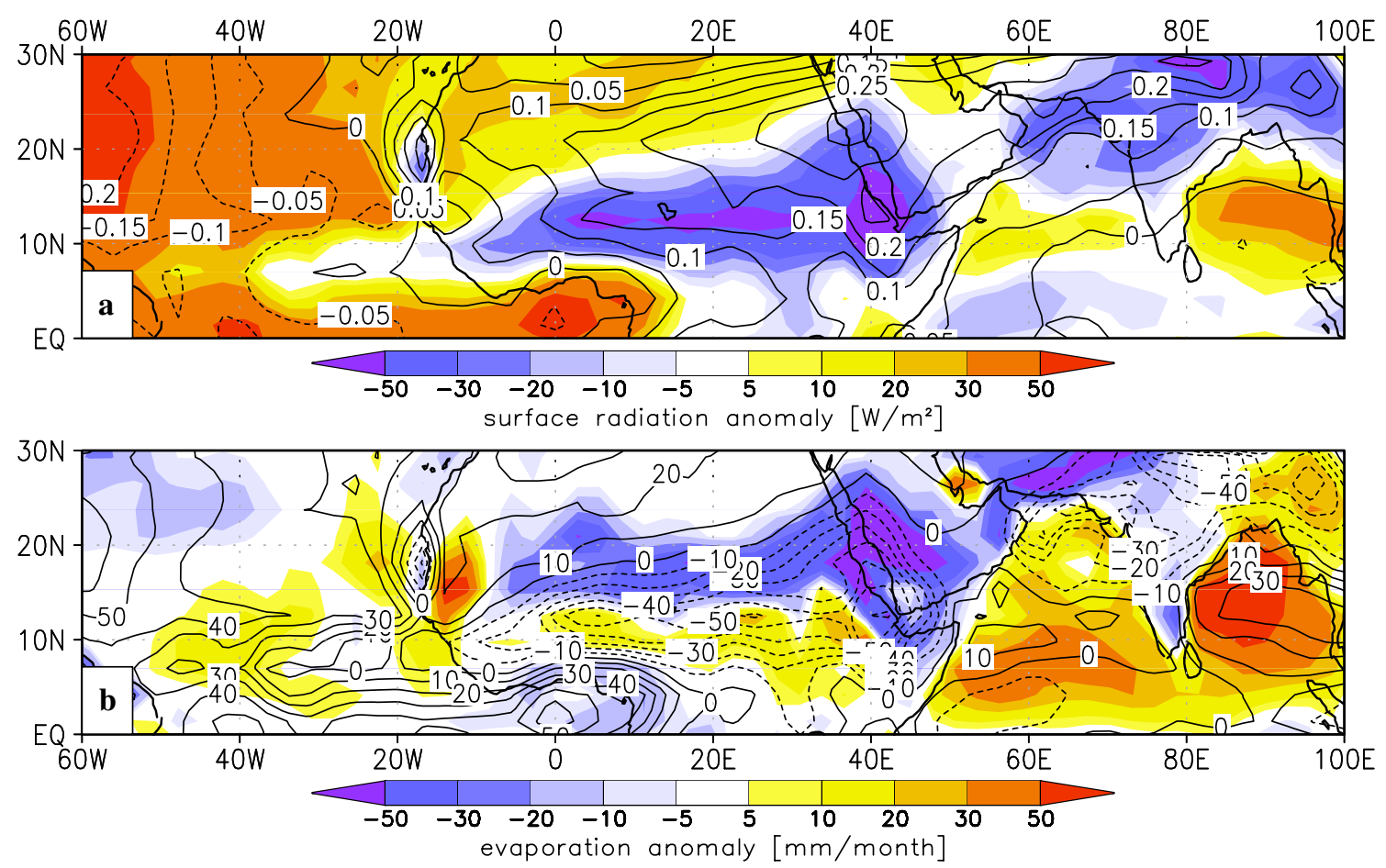

Fig. 5 Boreal summer (JJA) anomalies (EEM minus PI) of a shortwave surface radiation in $\mathrm{Wm}^{-2}$ (colours) and total cloud cover fraction (contours), and $\mathbf{b}$ evaporation rate in $\mathrm{mm} / \mathrm{month}$ (colours) and shortwave surface radiation in $\mathrm{Wm}^{-2}$ (contours)

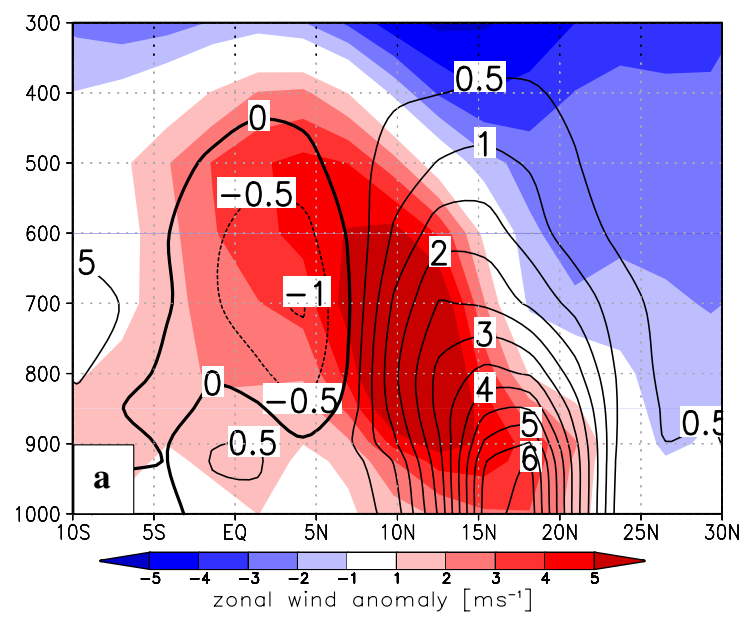

Fig. 6 Meridional cross-section of boreal summer (JJA) anomalies of EEM minus PI at $10^{\circ} \mathrm{E}$ of a zonal wind component in $\mathrm{m} / \mathrm{s}$ (colours) and specific humidity in $\mathrm{g} / \mathrm{kg}$ (contours), and $\mathbf{b}$ air temperature in $\mathrm{K}$

show the precipitation signal (Fig. 9a) together with the resulting isotopic composition of rainfall (Fig. 9b). Over Africa, about $50 \%$ of the summer signals are retained in the annual average.

\subsection{Sensitivity on vegetation cover and GIS}

Figures 10 and 11 show the effect of the changes made in $\mathrm{EEM}_{\mathrm{VEG}}$ and $\mathrm{EEM}_{\mathrm{GIS}}$, respectively. The vegetation

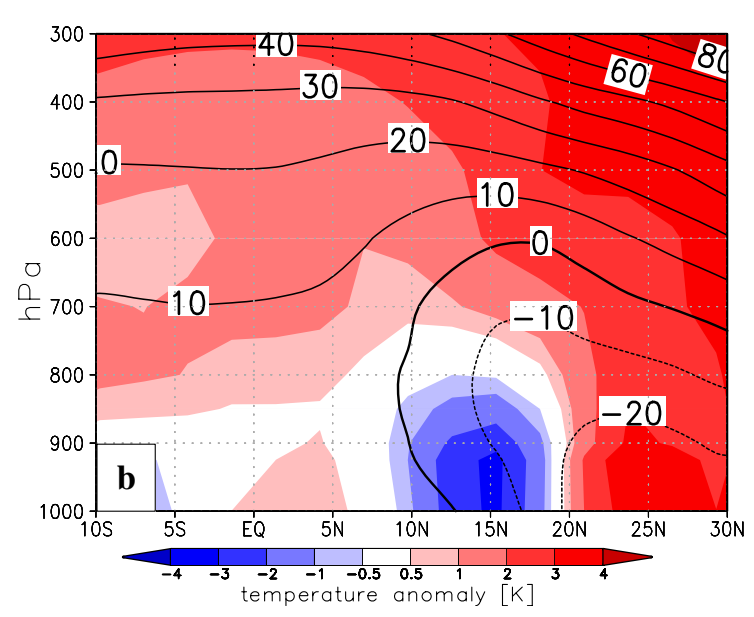

(colors) and geopotential height in gpm (contours). Red (blue) areas in a indicate eastward (westward) flow

changes result in an enhanced zonal wind component and a broadening of the cool belt, compared to EEM (Fig. 10a, b) with a positive precipitation anomaly north of $10^{\circ} \mathrm{N}$ and a negative anomaly south of $10^{\circ} \mathrm{N}$ (Fig. 10b). The effect of the changed GIS is negligible on the African continent (Fig. 11a, b). The decreased GIS produces a large temperature anomaly of up to $12 \mathrm{~K}$ over Greenland compared to PI, and $7 \mathrm{~K}$ compared to EEM (not shown). However, this anomaly does not reach subtropical and tropical 

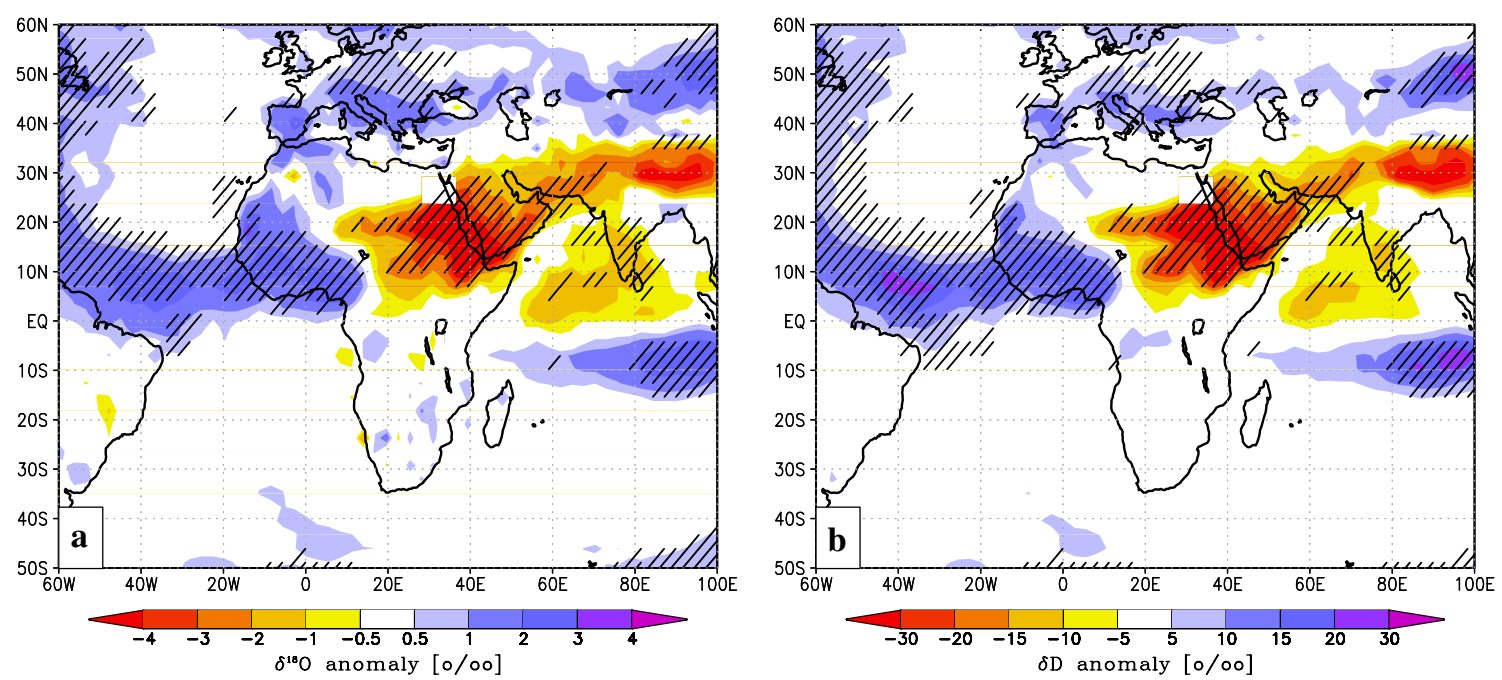

Fig. 7 Boreal summer (JJA) anomalies (EEM minus PI) of $\mathbf{a}{ }^{18} \mathrm{O}$ and $\mathbf{b}$ Deuterium isotopic composition of precipitation. Units are \%o VSMOW. Dashed areas indicate significant anomalies above $90 \%$ level
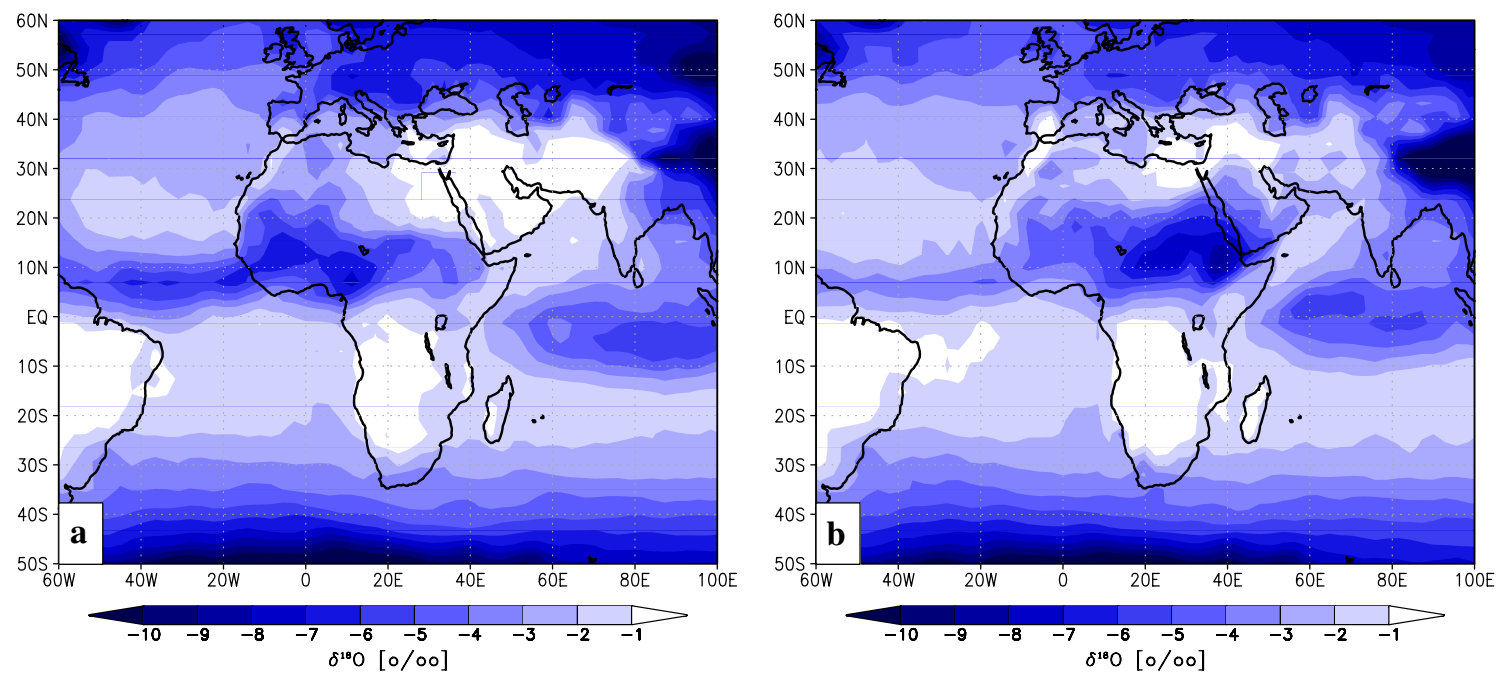

Fig. 8 Boreal summer (JJA) ${ }^{18} \mathrm{O}$ isotopic composition of a PI and b EEM precipitation. Units are \%o

regions. Figure $12 \mathrm{a}, \mathrm{b}$ show the wind and temperature anomalies of both sensitivity simulations compared to the PI simulation.

\section{Discussion}

\subsection{Climate variables}

In the Eemian, the temporal and spatial distribution of incoming solar radiation was different from pre-industrial insolation distribution. Due to a maximum in precession and a minimum in obliquity, the northern hemisphere insolation was increased during boreal summer months (JJA) (Berger 1978), while tropical insolation was decreased during boreal winter (DJF). Therefore, NH seasonality was increased, while SH seasonality was decreased. Eemian NH summer months (JJA) received more radiation than in the pre-industrial period, while in NH winter there was almost no change. The modelled annual mean near-surface temperature anomaly in this study is less than $0.5 \mathrm{~K}$, which is consistent with the summarised modelling estimates from IPCC AR4 (Jansen et al. 2007). In the following, we focus on boreal summer (JJA) climate. The excess in NH summer insolation leads to an increased surface temperature on the entire subtropical African continent north of $20^{\circ} \mathrm{N}$. Tropical Africa between $10^{\circ} \mathrm{N}$ and $10^{\circ} \mathrm{S}$ is not affected by a temperature change. This is due to the fact that vegetation and cloud cover prevent large temperature deviations. Additionally, the insolation anomaly in the tropics is lower than at middle and high latitudes. The summarized effect is a 

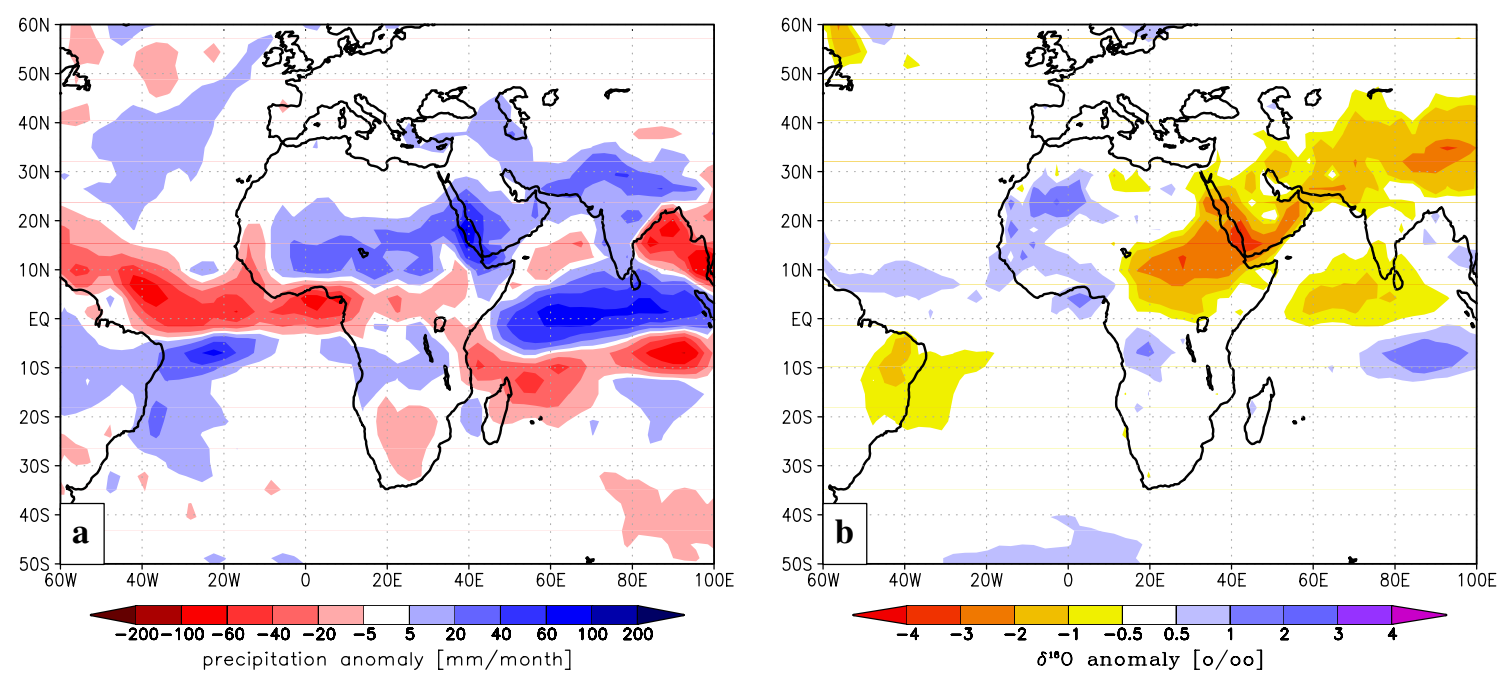

Fig. 9 Anomalies (EEM minus PI) of a modelled annual mean precipitation in $\mathrm{mm} / \mathrm{month}$, and $\mathbf{b}$ corresponding annual mean $\delta^{18} \mathrm{O}$ of precipitation in \%


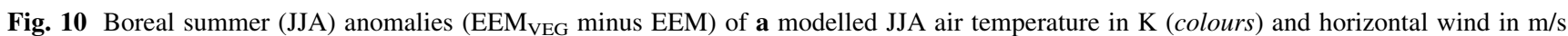
(arrows, reference arrow in the lower right corner) at $850 \mathrm{hPa}$ level, and b precipitation in $\mathrm{mm} / \mathrm{month}$

differential heating with warming in the north and almost unchanged surface temperature in the south. The corresponding air pressure distribution (low pressure anomaly in the north, no difference in the south) allows for a pressure gradient zone between $10^{\circ} \mathrm{N}$ and $20^{\circ} \mathrm{N}$. In this belt, the increased insolation does not lead to surface warming.

Instead, the pressure distribution forces a zonal flow, which is maintained over a long range from the Atlantic to the Red Sea. This flow carries moisture from the Atlantic over the continent, making it available for convection. Consequently, increased cloud cover (10-20\% over most of the cool belt area) caused by enhanced moisture availability prevents the excess shortwave radiation from reaching the surface. Mean surface radiation amounts decrease by up to $50 \mathrm{Wm}^{-2}$. Cooling is also caused by conversion of sensible heat into latent heat. In the northern part of the cool belt, evaporation is enhanced. Around $10^{\circ} \mathrm{N}$, however, evaporation is decreased in spite of increased precipitation. This opposed behaviour results from higher precipitation and evaporation values in the PI climate. Increased cloud cover in EEM effectively reduces evaporation, since in PI tropical evaporation rates already are very high. Increased precipitation in EEM therefore does not enhance evaporation rates in the southern part of the cool belt.

The ITCZ can be described as the tropical region where due to lower tropospheric convergence heat is transported from the surface to the upper troposphere by means of large cumulonimbus clouds (e.g. Holton 1992). The description of the ITCZ as a line or belt is therefore only valid in a time-averaged sense. Our simulations capture the mean 



Fig. 11 Boreal summer (JJA) anomalies (EEM $\mathrm{GIS}_{\mathrm{S}}$ minus EEM) of a modelled JJA air temperature in $\mathrm{K}$ (colours) and horizontal wind in m/s (arrows, reference arrow in the lower right corner) at $850 \mathrm{hPa}$ level, and b precipitation in $\mathrm{mm} / \mathrm{month}$
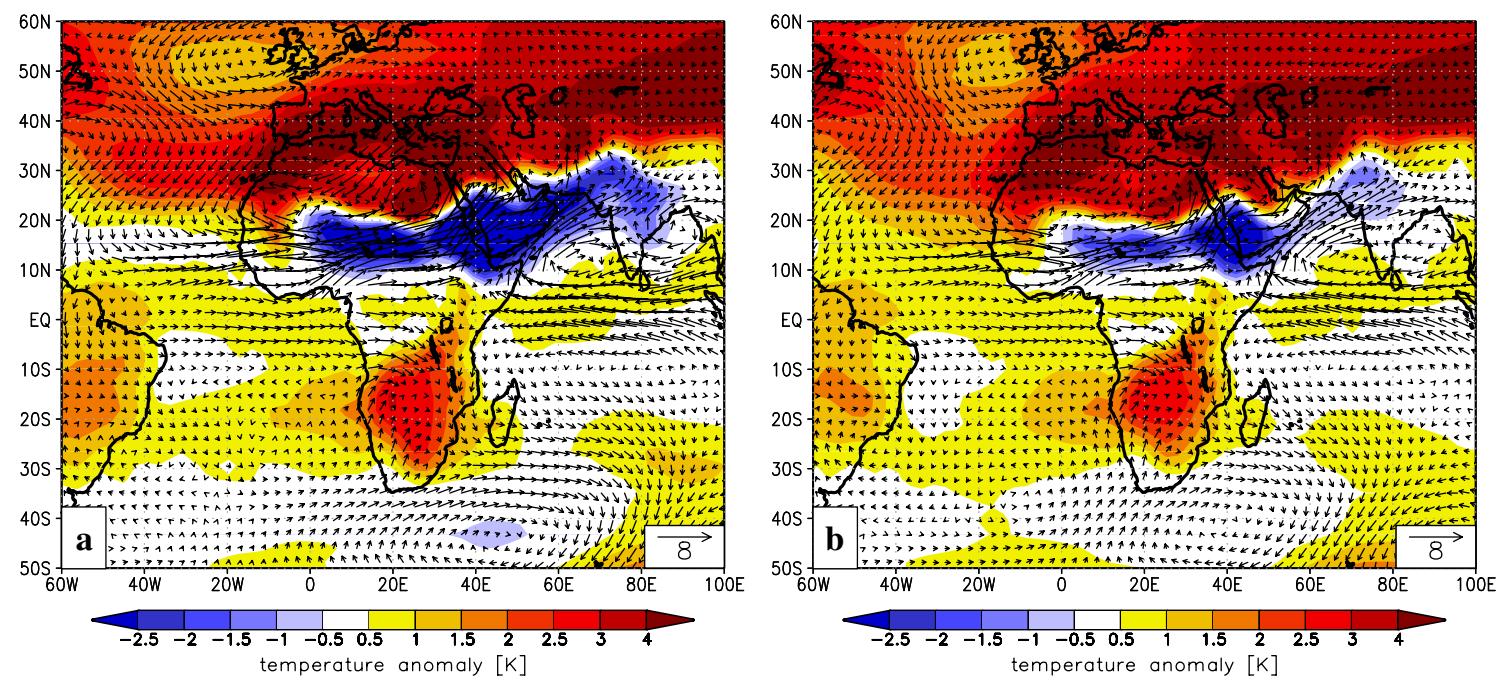

Fig. 12 Boreal summer (JJA) anomalies of modelled horizontal wind in $\mathrm{m} / \mathrm{s}$ (arrows), and air temperature at $850 \mathrm{hPa}$ level (colours) of a $\mathrm{EEM}_{\mathrm{VEG}}$ minus PI, and $\mathbf{b} \mathrm{EEM}_{\mathrm{GIS}}$ minus PI. Reference arrows in $\mathrm{m} / \mathrm{s}$ are shown in the lower right corner of the panels

effect due to the given spatial resolution of the GCM. Figure 4 shows the seasonally averaged convective zone in EEM and PI, respectively. The ITCZ position does only change over West Africa. In central and eastern Africa, the meridional position is almost unchanged. Only the strength of the convection is increased in EEM. Also, the area that is influenced by increased vertical velocity extends further to the north.

The difference in the meridional position of the rain belt is of secondary importance compared to the enhancement of the forced zonal moisture transport, which triggers the increased summer precipitation over Central Africa, the southern Red Sea region, the Arabian Peninsula and Mesopotamia/Pakistan/Northern India. A marked meridional displacement of the convergence zone is only visible in the
Indian Ocean (Fig. 3), where the band of maximum rainfall is shifted from $5^{\circ} \mathrm{S}$ (EEM) to $5^{\circ} \mathrm{N}(\mathrm{PI})$. On the African continent, there is no significant latitudinal difference in the position of the rain belt. We observe that the flow anomaly is not directed from high pressure over the Atlantic ocean towards north African low pressure, but mostly parallel to the north-south pressure gradient on the continent itself.

The features and anomalies discussed in the present paper also appear in the mid-Holocene simulations of the PMIP2/MOTIF Data Archive (Braconnot et al. 2007, not shown). The mid-Holocene might be comparable to the Eemian in terms of the annual distribution of orbital forcing anomalies. Therefore, our results appear to be a robust feature in interglacial African climate. 


\subsection{Isotopes}

The spatial anomaly of the isotopic rainfall composition, which has a dipole pattern (enrichment in the west, depletion in the east) is a mixed signal of several effects: the slight increase of the delta-values over the West African region can be attributed to a shorter time interval from the source (evaporation from the Atlantic) to the destination. This leads to fewer precipitation events and therefore to less isotopic depletion of the water vapour, that is advected over the continent.

Subsequent rain-out of the air masses due to enhanced transport of moisture from the Atlantic leads to eastward isotopic depletion, as the air is advected further across the African continent. Another cause for isotopic depletion is the so-called amount effect, described by Dansgaard (1964). However, the magnitude of depletion and the west-east gradient suggest that rain-out of the advected air masses (continental effect) is dominant. This is also supported by the fact that the area of significant change in convective precipitation (not shown) is very small compared to the area of significant large-scale precipitation anomaly.

Over the Arabian Peninsula, the negative temperature anomaly belt extends in north-east direction towards the Himalayas. The warm temperature anomaly to the northwest initiates a stronger north-eastern flow in the same manner as on the African continent. Here, the isotopic signature of precipitation also shows a depletion in EEM, which can be partly attributed to the amount effect (isotopic depletion due to increased rainfall within the rainbelt), since the moisture source is not only the tropical Atlantic but to a large part the nearby Gulf of Aden and the Arabian Sea, respectively. The extension of the modelled cool belt is supported by depleted $\delta \mathrm{D}$ values and increased precipitation from Oman stalagmite fluid inclusions (Fleitmann et al. 2003). The course of the narrow area of a north-south gradient in the geopotential height (see Fig. 2a) suggests that also the moisture from air masses that reach the Arabian Peninsula are influenced by the continental effect, and thus carry this information further towards northern India.

To a lesser extent, this mechanism also applies to the Congo basin region. Here, the lower troposphere warming occurs south of the resulting zonal flow over the Central Plateau. However, the spatial extent of the influenced region is not large enough to generate an isotopic signal comparable to the NH counterpart. Increased zonal moisture transport leads to enhanced precipitation in the Congo basin region, and thus to the modelled isotopic $\left(\delta \mathrm{D}, \delta^{18} \mathrm{O}\right)$ depletion of rainfall.

\subsection{Sensitivity on vegetation and GIS}

During the Eemian, large areas north of the present-day Sahel/Sahara boundary were covered by vegetation, which resulted in a reduction of the surface albedo and an increased moisture transport over the African continent. We estimated the effect of a changed vegetation distribution with the $\mathrm{EEM}_{\mathrm{VEG}}$ simulation. Figure 10a shows the resulting wind and temperature anomalies. The extended vegetated areas broaden the belt of the air temperature anomaly. The precipitation anomaly shows that a large fraction of the transported water is precipitating between $15^{\circ} \mathrm{N}$ and $25^{\circ} \mathrm{N}$. A reduction of rainfall occurs south of the positive anomaly. However, the structure does not change significantly compared to the EEM simulation (Fig. 12a). Similar results are presented by Schurgers et al. (2007). They show that the West African precipitation anomaly extends further northward than the East African anomaly, whereas our results over Northeast Africa show that the precipitation anomaly covers large parts of the Red Sea region. However, the structure of the anomalies does not depend on the vegetation. The belt of lower air temperature between $10^{\circ} \mathrm{N}$ and $20^{\circ} \mathrm{N}$ appears in all simulations shown by Schurgers et al. (2007). The effects of dynamic vegetation therefore appear to be of second order compared to the effect of changes in orbital forcing.

The effect of the decreased ice volume of the GIS on the African continent appears to be very small (Fig. 11). In our sensitivity study, the largest anomaly between EEM and $\mathrm{EEM}_{\mathrm{GIS}}$ is located over Greenland itself (not shown). The resulting near-surface changes over Greenland match the modelled values shown by Otto-Bliesner et al. (2006). The air temperature response extends over the Arctic and large parts of polar latitudes. However, the influence on the tropics and in particular the African tropics is relatively small. The flow anomaly, which is discussed in the present paper, is not changed significantly (see Fig. 11a). The areas that are effected by the Eemian anomalies of wind, temperature, precipitation and cloud cover remain almost unchanged in position and extent.

\subsection{Model-data comparison}

The modelled isotopic compositions of precipitation resemble measured isotope values from various sources. The isotopically depleted water masses that are advected towards the large catchment area of the Nile river can be identified in Mediterranean sediment cores (Rohling et al. 2004). In their study (Rohling et al. 2004), show increased Eastern Mediterranean alkenone-based SST $(+4 \mathrm{~K})$ and depleted $\delta^{18} \mathrm{O}$ values of planktic foraminiferal species $(1-3 \%$ ) during deposition of sapropel S5.

Fleitmann et al. (2007) showed a change from wet to dry conditions in $\delta^{18} \mathrm{O}$ of speleothem records from southern Oman during the Eemian. The observed shift of the isotopic composition of $2-3 \%$ matches our modelled anomaly in this region $(3 \%$ ). Reichart et al. (1997) show 
oxygen isotopic data from a sediment core from Murray Ridge north of the Arabian Basin. Their data suggests increased summer precipitation during MIS 5e. Wang et al. (2008) show composite time series of $\delta^{18} \mathrm{O}$ from the Sanbao cave (Central China) and Hulu cave (East China). They compare very well with the Vostok ice core $\delta^{18} \mathrm{O}$ time series, and the anomaly of $1-2 \%$ corresponds well to our findings $(2 \%)$. Schefuß et al. (2005) reported depleted mid-Holocene $\delta \mathrm{D}(-150 \%$ around $6 \mathrm{ka} \mathrm{BP}$, compared to $-135 \%$ VSMOW at the top of the sediment core) in plant waxes from the Congo catchment region. They attribute the mid-Holocene depletion to an increased amount of precipitation. However, our simulation shows a slight enrichment in $\delta^{18} \mathrm{O}(0.5-1 \%$ o $)$ and $\delta \mathrm{D}(5-10 \%)$, respectively, in the Congo basin region, which is consistent with enriched $\delta^{18} \mathrm{O}$ over West Africa. We attribute this opposite trend to higher temperatures over the Congo basin, which result in a depletion in spite of the increased amount of precipitation. The Dome $\mathrm{C}$ ice core deuterium anomaly of about $20 \%$ (Augustin et al. 2004) is also observed in the EEM-PI anomaly. Andersen et al. (2004) and Suwa et al. (2006) report Greenland $\delta^{18} \mathrm{O}$ anomalies of $2-3 \%$ which is more than our EEM-PI anomaly, but less than our modified EEM simulation that includes the reduction of the Greenland ice sheet during the Eemian. European proxy data sources include Kattegat $\delta^{18} \mathrm{O}$ from shells (Burman and Passe 2008) that translate to summer SST which were 1-3 K higher in the Eemian than today. Our temperature anomaly is around $1 \mathrm{~K}$ for this region.

\section{Conclusions}

We compare the simulated pre-industrial African climate with Eemian climate, a period which is characterised by a boreal summer insolation maximum. The modelled climates show considerable differences in wind, temperature, and precipitation amount. The direct simulation of $\mathrm{H}_{2}^{18} \mathrm{O}$ and HDO allows the interpretation of the isotopic rainfall composition with respect to the climatic anomalies. The boreal summer season shows the largest anomalies, due to the external insolation forcing. The mechanism that is responsible for the modelled climatic anomalies and the isotopic precipitation response can be summarized as follows:

- During the Eemian maximum NH summer insolation the excess insolation leads to a warming of the $\mathrm{NH}$ subtropics. The meridional temperature gradient over $\mathrm{NH}$ Africa increases, and the resulting pressure gradient drives a zonal flow between $10^{\circ} \mathrm{N}$ and $20^{\circ} \mathrm{N}$. The anomaly extends from about $40^{\circ} \mathrm{W}$ to $80^{\circ} \mathrm{E}$. Additional cloud formation and rainfall between $10^{\circ} \mathrm{N}$ and $20^{\circ} \mathrm{N}$ due to increased convection cause a pronounced cooling in these latitudes. From our results we conclude that the climatic differences between EEM and PI are mainly caused by zonal moisture transport and thus affect the whole northern African continent. We also observe the meridional shift of the ITCZ as reported by previous studies (e.g. Kutzbach et al. 1996), but this shift alone does not explain the anomalies in the modelled climate variables and water isotopes.

- The isotopic composition of precipitation reacts strongly on the rainfall redistribution: the west-east gradient of the isotopic rainfall composition reverses during periods of increased $\mathrm{NH}$ summer insolation. This is observed in several archives of terrestrial $\delta^{18} \mathrm{O}$. Our study reveals that the large zonal isotopic gradient is possible due to the forcing of the flow anomaly which is directed perpendicular to the large-scale pressure gradient. The forcing is persistent from the Atlantic to the Red Sea area, and therefore we observe a continuous depletion over the whole width of the continent. In the Indian monsoon vicinity, isotopic rainfall depletion occurs to a large part via the amount effect, since the source water is mixed with water masses that originate from sources close to the precipitation sites.

In this study, we present a mechanism that explains changes in African isotopic rainfall composition during interglacial insolation maxima. The model indicates that the North African anomalies are one of the largest signals on the globe. The zonal redistribution of water vapor may represent an eigenmode of palaeoclimate and possibly future climate changes. For further testing of our modelling, the analysis of terrestrial proxy archives from the East African continent (such as lake sediments) would be highly valuable. As a next step we propose isotope-enabled coupled ocean-atmosphere simulations, including fractionation processes in dynamic vegetation and sea-ice. Such an approach would allow a comparison with the whole range of proxy archives (terrestrial and marine) in an Earth system model, since isotopic signatures are modelled consistently in all components of the water cycle.

Acknowledgments This study was funded through DFG-Research Center/Excellence Cluster "The Ocean in the Earth System". We thank Jürgen Pätzold and Thomas Felis for the stimulating discussions and for the insight in the work of retrieving proxy data. We are grateful to Martin Werner and Martin Losch for comments and discussions during the development of the manuscript.

\section{References}

Andersen K, Azuma N, Barnola J, Bigler M, Biscaye P, Caillon N, Chappellaz J, Clausen H, DahlJensen D, Fischer H, Fluckiger J, Fritzsche D, Fujii Y, Goto-Azuma K, Gronvold K, Gundestrup 
N, Hansson M, Huber C, Hvidberg C, Johnsen S, Jonsell U, Jouzel J, Kipfstuhl S, Landais A, Leuenberger M, Lorrain R, Masson-Delmotte V, Miller H, Motoyama H, Narita H, Popp T, Rasmussen S, Raynaud D, Rothlisberger R, Ruth U, Samyn D, Schwander J, Shoji H, Siggard-Andersen M, Steffensen J, Stocker T, Sveinbjornsdottir A, Svensson A, Takata M, Tison J, Thorsteinsson $\mathrm{T}$, Watanabe $\mathrm{O}$, Wilhelms F, White $\mathrm{J}$, and $\mathrm{N}$ Greenland Ice Core Project (2004) High-resolution record of Northern Hemisphere climate extending into the last interglacial period. Nature 431(7005):147-151

Augustin L, Barbante C, Barnes P, Barnola J, Bigler M, Castellano E, Cattani O, Chappellaz J, DahlJensen D, Delmonte B, Dreyfus G, Durand G, Falourd S, Fischer H, Fluckiger J, Hansson M, Huybrechts P, Jugie R, Johnsen S, Jouzel J, Kaufmann P, Kipfstuhl J, Lambert F, Lipenkov V, Littot G, Longinelli A, Lorrain R, Maggi V, Masson-Delmotte V, Miller H, Mulvaney R, Oerlemans J, Oerter H, Orombelli G, Parrenin F, Peel D, Petit J, Raynaud D, Ritz C, Ruth U, Schwander J, Siegenthaler U, Souchez R, Stauffer B, Steffensen J, Stenni B, Stocker T, Tabacco I, Udisti R, vande R Wal, vanden Broeke M, Weiss J, Wilhelms F, Winther J, Wolff E, Zucchelli M, and EPICA Community Members (2004) Eight glacial cycles from an Antarctic ice core. Nature 429(6992):623-628

Berger AL (1978) Long-term variations of daily insolation and quaternary climatic changes. J Atmos Res 35:2361-2367

Braconnot P, Otto-Bliesner B, Harrison S, Joussaume S, Peterschmitt J-Y, Abe-Ouchi A, Crucifix M, Driesschaert E, Fichefet T, Hewitt CD, Kageyama M, Kitoh A, Lan A, Loutre M-F, Marti O, Merkel U, Ramstein G, Valdes P, Weber SL, Yu Y, Zhao Y (2007) Results of PMIP2 coupled simulations of the MidHolocene and Last Glacial Maximum-Part 1: experiments and large-scale features. Clim Past 3(2):261-277

Burman J, Passe T (2008) Oceanography in northwestern Europe during the last interglacial from intrashell delta O-18 ranges in Littorina littorea gastropods. Quat Res 70(1):121-128

Craig H (1961) Isotopic variations in meteoric waters. Science 133:1702-1703

Dansgaard W (1964) Stable isotopes in precipitation. Tellus 4:436468

Doherty R, Kutzbach J, Foley J, Pollard D (2000) Fully coupled climate/dynamical vegetation model simulations over Northern Africa during the mid-Holocene. Clim Dyn 16(8):561-573

Felis T, Lohmann G, Kuhnert H, Lorenz S, Scholz D, Pätzold J, Al-Rousan S, Al-Moghrabi S (2004) Increased seasonality in Middle East temperatures during the last interglacial period. Nature 429:164-168

Fleitmann D, Burns SJ, Neff U, Mangini A, Matter A (2003) Changing moisture sources over the last 330,000 years in Northern Oman from fluid-inclusion evidence in speleothems. Quat Res 60:223-232

Fleitmann D, Burns S, Mangini A, Mudelsee M, Kramers J, Villa I, Neff U, Al-Subbary A, Buettner A, Hippler D, Matter A (2007) Holocene ITCZ and Indian monsoon dynamics recorded in stalagmites from Oman and Yemen (Socotra). Quat Sci Rev 26:170-188

Hoffmann G, Werner M, Heimann M (1998) Water isotope module of the ECHAM atmospheric general circulation model: a study on timescales from days to several years. J Geophys Res 103(D14):16,871-16,896

Holton JR (1992) An introduction to dynamical meteorology. Academic Press, Dublin

Jansen E, Overpeck J, Briffa KR, Duplessy J-C, Joos F, MassonDelmotte V, Olago D, Otto-Bliesner B, Peltier WR, Rahmstorf S, Ramesh R, Raynaud D, Rind D, Solomina O, Villalba R, Zhang D (2007) Paleoclimatology. In: Solomon S, Qin D, Manning M, Chen Z, Marquis M, Averyt KB, Tignor M, Miller
HL (eds) Climate change 2007: the physical science basis. Contribution of working group $i$ to the fourth assessment report of the intergovernmental panel on climate change. Cambridge University Press, Cambridge, pp 433-497

Jouzel J, Lorius C, Petit JR, Genthon C, Barkov NI, Kotlyakov VM, Petrov VM (1987) Vostok ice core-a continuous isotope temperature record over the last climatic cycle $(160,000$ years). Nature 329:403-408

Jouzel J, Hoffmann G, Koster RD, Masson V (2000) Water isotopes in precipitation: data/model comparison for present-day and past climates. Quat Sci Rev 19(1-5):363-379

Kutzbach JE, Liu Z (1997) Response of the African monsoon to orbital forcing and ocean feedbacks in the middle Holocene. Science 278:440-443

Kutzbach J, Bonan G, Foley J, Harrison SP (1996) Vegetation and soil feedbacks on the response of the African monsoon to orbital forcing in the early to middle Holocene. Nature 384:623-626

Legutke S, Voss R (1999) The Hamburg ocean-atmosphere coupled general circulation model ECHO-G. Technical report, Deutsches Klimarechenzentrum, Hamburg

Lhomme N, Clarke GKC, Marshall SJ (2005) Tracer transport in the Greenland Ice Sheet: constraints on ice cores and glacial history. Quat Sci Rev 24(1-2):173-194

Lohmann G, Lorenz SJ (2007) Orbital forcing on atmospheric dynamics during the last interglacial and glacial inception. In: Sirocko F, Litt T, Claussen M, Sanchez-Goni MF (eds) The climate of past interglacials, Elsevier, Amsterdam, pp 527-545

Lorenz SJ, Lohmann G (2004) Acceleration technique for Milankovitch type forcing in a coupled atmosphere-ocean circulation model: method and application for the holocene. Clim Dyn 23:727-743

Merlivat L, Jouzel J (1979) Global climatic interpretation of the deuterium-oxygen-18 relationship for precipitation. J Geophys Res 84(NC8):5029-5033

Montoya M, von Storch H, Crowley TJ (2000) Climate simulation for $125 \mathrm{kyr}$ BP with a coupled ocean-atmosphere general circulation model. J Clim 13(6):1057-1072

Otto-Bliesner BL, Marsha SJ, Overpeck JT, Miller GH, Hu AX (2006) Simulating arctic climate warmth and icefield retreat in the last interglaciation. Science 311(5768):1751-1753

Reichart G, denDulk M, Visser H, van der Weijden C, Zachariasse W (1997) A $225 \mathrm{kyr}$ record of dust supply, paleoproductivity and the oxygen minimum zone from the Murray ridge (northern Arabian sea). Palaeogeogr Palaeoclimatol Palaeoecol 134(1-4): 149-169

Rohling EJ, Cane TR, Cooke S, Sprovieri M, Bouloubassi I, Emeis KC, Schiebel R, Kroon D, Jorissen FJ, Lorre A, Kemp AES (2002) African monsoon variability during the previous interglacial maximum. Earth Planet Sci Lett 202:61-75

Rohling EJ, Sprovieri M, Cane T, Casford JSL, Cooke S, Bouloubassi I, Emeis KC, Schiebel R, Rogerson M, Hayes A, Jorissen FJ, Kroon D (2004) Reconstructing past planktic foraminiferal habitats using stable isotope data: a case history for Mediterranean sapropel S5. Mar Micropaleontol 50(1-2):89-123

Rossignol-Strick M (1983) African monsoons, an immediate climate response to orbital insolation. Nature 304:46-49

Rozanski K, Araguas-Araguas L, Konfiantini R (1993) Isotopic patterns in modern global precipitation. Geophys Monogr 78:1-36

Schefuß E, Schouten S, Schneider RR (2005) Climatic controls on central African hydrology during the past 20,000 years. Nature 437:1003-1006

Schmidt GA, LeGrande AN, Hoffmann G (2007) Water isotope expressions of intrinsic and forced variability in a coupled ocean-atmosphere model. J Geophys Res 112:D10103

Schurgers G, Mikolajewicz M, Groeger U, Maier-Reimer E, Vizcaino M, Winguth A (2007) The effect of land surface changes on Eemian climate. Clim Dyn 29:357-373 
Suwa M, von Fischer J, Bender M, Landais A, Brook E (2006) Chronology reconstruction for the disturbed bottom section of the GISP2 and the GRIP ice cores: implications for Termination II in Greenland. J Geophys Res 111:D02101

Tzedakis PC (2007) Seven ambiguities in the Mediterranean palaeoenvironmental narrative. Quat Sci Rev 26(17-18):2042-2066

vander Meer MTJ, Baas M, Rijpstra WIC, Marino G, Rohling EJ, Damste JSS, Schouten S (2007) Hydrogen isotopic compositions of long-chain alkenones record freshwater flooding of the
Eastern Mediterranean at the onset of sapropel deposition. Earth Planet Sci Lett 262(3-4):594-600

Wang Y, Cheng H, Edwards RL, Kong X, Shao X, Chen S, Wu J, Jiang X, Wang X, An Z (2008) Millennial- and orbital-scale changes in the East Asian monsoon over the past 224,000 years. Nature 451(7182):1090-1093

Werner M, Heimann M, Hoffmann G (2001) Isotopic composition and origin of polar precipitation in present and glacial climate simulations. Tellus 53B:53-71 